\title{
A Study of Collision and Fusion of Eastern and Western People-oriented Management Philosophy
}

\author{
Guiling Wei \\ School of Business, Sias International University \\ Renming Road NO. 168, Xinzheng 451150, China \\ Caiyun Zhang (Corresponding author) \\ School of Foreign Languages, Sias International University \\ Renming Road NO. 168, Xinzheng 451150, China \\ E-mail: caiyunzhang2006@hotmail.com
}

Received: August 11, 2011

doi:10.5539/ass.v7n12p239
Accepted: September 27, 2011

Published: December 1, 2011

URL: http://dx.doi.org/10.5539/ass.v7n12p239

\begin{abstract}
Eastern people-oriented management philosophy, traditional Chinese management culture as its core, emphasizes on culture and ethical guidance. Before the 17th century, this kind of management thinking has brought tremendous economic, social, cultural and other aspects prosperity to the East. However, in modern times, as a result of decline of the east and rapid rise of the west, management theory has been rooted in western management ideology. The 21 st century, is a new stage of management theory development, which witnesses world's continuous economic development, increasingly regional cooperation, and all these contribute to the unprecedented collision and fusion of eastern and western "people-oriented" management philosophy. The main orientation of future management development should be oriental management culture as its core, and absorb scientific achievements of western management culture, in order to enrich the treasure trove of management philosophy so as to promote the great fusion of eastern and western management cultures.
\end{abstract}

Keywords: People-oriented, Management philosophy, Collision and fusion

\section{Introduction}

Eastern and western people-oriented management philosophy, deriving from eastern and western management cultural traditions respectively, are not the same as Chinese traditional humanistic management philosophy or western contemporary human-centered management thinking. This article analyzes comparatively eastern and western people-oriented management thoughts to explore the people-oriented management philosophy. People-oriented management philosophy is the management of the people, by the people and for the people; and it attaches great importance to people's guiding role during management process, and it values people's dignity, human values, and establishes essentially human-centered idea in all activities. Therefore, it views arousing people's enthusiasm and tapping their potentials as the main responsibilities or duties of a manager.

The 21st century, is a new stage of management theory development, which witnesses world's continuous economic development, increasingly regional cooperation, and all these contribute to the unprecedented collision and fusion of eastern and western "people-oriented" management philosophy. With the in-depth impact of economic globalization, the clash of civilizations, exchanges and cooperation have become the main topics and the eternal melody of the globalization process. Thus, nowadays, communication between divergent cultures of different values and harmonious development become inevitable trends. The main orientation of future management development should be oriental management culture as its core, and absorb scientific achievements of western management culture, in order to enrich the treasure trove of management philosophy so as to promote the great fusion of eastern and western management cultures. 


\section{Western "People-Oriented" Management Philosophy}

\subsection{Ancient Greek Culture}

People-oriented management ideas in western culture can be traced back to ancient Greece. In the essence of ancient Greek culture, the value of individual existence has been publicized. Protagoras states that man is the measure of all things; the scale of existing things why they do exist, and also scale of non-existing things why they do not exist (Philosophy Department of Beijing University, 1982). It is the sole criterion--the individual values all things, that places the individual in a supreme position, and encourages ancient Greeks to fully display their wisdom and strength to create the splendid ancient Greek civilization.

\subsection{Western Management Thoughts in $18^{\text {th }}$ Century}

In 18th century, French materialism and German classical philosophy found and develop; meanwhile, researches on human climb at a new stage. Adam Smith, classical economist, puts forward the famous "economic man" idea. "Economic man" is also called "Only Win", "materialism", "economic rational man", who has the nature of selfishness. The representative figures, who take economic man as human assumptions in management thought, include Taylor, Fayol and Weber. Also, American psychologist McGregor's X theory is based on "economic man" hypothesis( $\mathrm{Xu}, 2000)$, which bases on hedonism philosophy, and views people as irrational, innately lazy, and born with the pursuit of self-interests to get the physical needs and security needs met. Actually, it considers individual as a complete one, but denies individuals' social nature. Furthermore, Taylor's "carrot and stick" policy, which regards human as "economic man", indicates human should be treated as appendages of a machine even animal. In truth, "economic man" management thought can not inspire the employee's devotion and sense of ownership; but only form the employment thinking--to how much money, how much work is.

With the further development of capitalistic enterprises, $\mathrm{X}$ theory is gradually revealing its limitations. The concept, stimulating employees' enthusiasm with money, is frustrated in practice, for its neglect of human's initiative and emotion increasingly noticed by the public. American Australian Aden De Mayo puts forward the famous "Hawthorne experiment", which proposes the "social man" concept: human (Xu 2000). Human, not only has economic needs and desires, as well as non-economic-social and psychological pursuits, including pursuit of interpersonal friendship, security, sense of belonging and respect, and the need for being recognized, and so on. Therefore, he believes that people are not economic men with money as the merely driving force, but "social man." People are not isolated individuals, but unique social animals, who can fully realize human freedom only in the collective, and achieve human meaning only at work and within the social relations established through work. "Social man" hypothesis, whose essence is the establishment of a harmonious interpersonal relationship in management, puts forward the equality, democracy and a sense of ownership of the employees to some extent. And the corresponding management theory, "participative management" is $\mathrm{Y}$ theory.

\subsection{Maslow's Hierarchy of Needs Theory}

In the late 1950s, hierarchy of needs theory and behavioral sciences come into being. Some managers feel that it not enough to explain the motives of all the behaviors by satisfying the need of interpersonal relationship. People are not just "social man", but "achieved man", whose principal motivation source of work is to fully play their potentials and achieve self-realization. Achieved man, also is known as self-actualizing man. It is the view on human nature that proposed by humanist psychologist Maslow (1943). Maslow's hierarchy of needs theory includes physiological needs, security needs, communication needs, esteem needs, self-actualization needs. The former two low-level needs are biological needs of people; the latter three social and psychological needs are the needs of self-actualizing, which are the highest level of human needs. Self-actualizing refers to the full development of individual talents, perfected personality, and the full realization of the individual's all potentials and value of a free, healthy, fearless person.

\subsection{Contingency Theory}

After the world war II, the scientific management schools characterized by extensive use of mathematical methods and computer emerge in the west, and it enters the "management jungle" stage named by American management expert Koontz, with the milestone --Contingency Theory put forward by American Morse and Roche in 1970s. Contingency means appropriate management measures should be taken under specific circumstance, and it differs from X theory, nor Y theory, so it is called beyond theory Y (Horn 2000; Huang 2000; Xu 2000; Yang 1999). This theory views the theories --economic man and social man-- are one-sided on the assumption of human nature, since they don't take the influence of personality, divergent needs and objective environment into consideration. Furthermore, it holds that human should be complex person who can respond 
appropriately due to variable time, place and a variety of situations. Therefore, there is no such omnipotent management method applicable for any person, any society, and any class. It is on the basis of complex person hypothesis of human nature that contingency theory comes into being.

Looking through the development of western management culture, management on human is the core, and it experiences a gradually deepening process, from economic man, social man, and achieved man to complex man. During this process, management transforms from human behavior management to human nature management. Economic man hypothesis, which thinks highly of material factors, but neglects interpersonal relationships, tries to mobilize the enthusiasm of the staff with material incentives; social man hypothesis, attaches great importance to interpersonal relationships, but to some extent ignores the basic security role of substance; achieved man hypothesis, shifting the focus of management from human factors to the importance of working environment, it emphasizes the need to create a suitable working environment and conditions for staff who may give full play to their potentials and fully develop their expertise and creativity under such conditions.

\section{Eastern People-oriented Management Philosophy}

Oriental people-oriented management philosophy, based on Chinese management practice and theoretical exploration of management philosophy, is a set of theoretical system, which mainly comes from various of academic schools in ancient China, such as Confucianism, Taoism, Mohists, Legalism, and military strategists, I Ching and Buddhism and so on.

\subsection{Guan Zhong's People-oriented Management Thinking}

Guan Zhong is the first statesman in ancient China that proposes people-oriented management thought. He says the king should be people-oriented in state management: the state will be stable if the rationale is solid; otherwise, the state will be risky if the rationale is in chaos (Chen 2006; Yan 1999). It reminds country rulers that the country may go wrong if it is not people-oriented in management. Thus, Guan Zhong's cognition of human values, human status and role reaches a very high level. Moreover, Guan Zhong holds human's desires should be respected and met in scientific and effective management. Guan also says, when one is well fed, he becomes aware of honor and disgrace; when his barns are full, he actually knows etiquette. In addition, he divides human desires into two levels, "barns are full" and "well-fed" as the low level of material desire, "knowing etiquette" and "awareness of honor and disgrace" as the high-level of spiritual needs.

\subsection{Confucian People-oriented Management Thinking}

In the late Spring and Autumn period, a great Chinese thinker and educator, Confucius, the founder of Confucianism, pays more attention to human and emphasizes human values. He states that in the nature of the world, human is of the highest importance (Cai 2006; Zhong 2007). Also, he advocates deep spirit within humanism is benevolence, established as the core of the whole Confucianism. Benevolence, also benevolent persons, or people, in short, is morality. Once, Confucius is asked about the government management by King Ai of Lu kingdom. Confucius replies, the core of management is the manager, and the most importance is his self-cultivation. Being benevolent means loving people. Among those, the greatest benevolence is to love one's own parents. It can be seen, Confucius has put the human factors in the first place. Therefore, the essence of Confucian ideology is "benevolence", i.e. people-oriented.

In people-oriented management practices, Confucius advocates leaders themselves should set examples for others, and should do it prior to others. Confucius states, if the ruler is personally upright, all will go well even though he does not give orders. But if he is not personally upright, even though he repeatedly gives orders, they will not be obeyed. (Cai 2006; Zhong 2007) It notes that only leaders themselves manage themselves well, they can manage others; the leaders' examples are silent commands. To be personally upright, self-cultivation should be the first for the leaders. Therefore, Confucius proposes a viewpoint of "self-cultivation in order to be respected".

\subsection{Mencius's People-oriented Management Thinking}

Mencius constructs his ideology from the hypothesis--man's nature is good. He proposes a theory: compassion is in everyone; good and evil is in everyone; respect is in everyone; right or wrong is in everyone (Yan 1999). Mencius attaches great importance to human's role in governing a country. He says, King Jie and Zhou in Shang dynasty lose their control on the state, for missing the people. Losing people means losing supports. There is a tactics in ruling the world: obtaining the people equals to obtaining the world; moreover. And also there is a tactics in obtaining the people: obtaining the hearts or support equals to obtaining the people. Based on this understanding, Mencius points out the famous ranking: the people rank the highest, then the country, and the last the king. Furthermore, this kind of person is invincible throughout the world. Mencius believes that in 
implementing people-oriented management, people's support should be the first, so it is necessary to recognize and meet people's material, security and social needs.

\subsection{Xun Zi's People-oriented Management Thinking}

Famous ancient Chinese educator, thinker and a Confucian representative, Xun $\mathrm{Zi}$, sets forth evil nature of human theory opposing to Mencius, but exactly the same on human status and role with Mencius. And Xun Zi clearly states human being is the spirit of all the creatures. He holds that water and fire have breath but no life; vegetations are animate, but without awareness; animals have awareness but no righteousness. In contrast, human beings have all these items, so they are the most valuable on the world (Yan 1999; Yang 2000; Chen 2006). It is because of the difference from other creatures -- awareness and righteousness in human, that human can form an orderly society, manage things, and become the world's most distinguished ones. This is a full recognition of human's status and role.

Xun Zi believes that once a man was born, he was bound to generate desires. There are three laws of desire development: the first is desire is unavoidable. In other words, everyone has desires. The second one, desire is boundless: human has endless desires. The third is the growth of substance and desire in mutual influence and restriction. Xun Zi further analyzes if those desires can not be satisfied, it may lead to war, disaster and poverty. In order to promote social development and prevent disasters, etiquette should be set to foster human's reasonable desires, and control unreasonable ones meanwhile. Also, human desires should be adjusted to the growth of society.

\section{Influence of People-Oriented Management Thought in Traditional Chinese Culture}

People-oriented management philosophy in traditional Chinese culture has a profound influence on later generations. The essence of it requires the monarch to weigh people, love people, and not to despise the people from the angle of bringing peace to country, therefore, the people are the foundation of ruling. It requires the monarch to benefit people and enrich people in economy, which should be viewed as the statecraft; also, it requires them to advocate benevolence and oppose amassing wealth by heavy taxation in politics. This argument is conducive to social stability, the development of productivity and society. Past dynasties of China have learned the essence of management from this thought. Confucian people-oriented management philosophy can go beyond purely relations between substance and money to a certain extent, and concentrate on people and operate with "people-oriented" philosophy, which is the actual use in commercial activities of Confucian understanding of human-centered philosophy when treat things, benefiting people, putting oneself in the place of another and putting things in the place of human. They are mainly reflected in three aspects:

To begin with, management of people is the basis. It considers that although business cannot do without money, the fundamental lies in human, which has been seen as the largest and most valuable capital in business in Confucianism. Therefore, the human values should be respected.

Then, it advocates operation for the people. They should get a return and profit by loving and obtaining people, but oppose to grabbing and getting profits by unscrupulous and predatory means.

And last, righteousness and faith are the roots of business ethics. While Confucian entrepreneurs are obeying the law, they emphasize inherent moral self-discipline, and conscientiously abide by the standards of business ethics, especially the most important righteousness and faith. Valuing righteousness is not only one of the defined essences of Confucianism, but an important feature of Confucian thoughts. It is no denying that all the commodity operators seek for profit; their direct objective is always to obtain more profits, which is determined by the nature of the commodity. However, Confucian entrepreneurs can weigh profit, but they cannot seek for it absolutely, i.e. the profit cannot be the sole purpose. It is advocated that righteousness cannot be forgotten while seeking for profit, but keep righteousness in mind while seeing profit in the eye, and driving profit with righteousness. Under certain circumstance, righteousness may be got beyond profit; even profit can be ridded with righteousness. The spirit of Confucian entrepreneurs, weighing righteousness, may temporarily undermine the benefits on the surface, but the credit can be got by their righteousness, which may bring them much better and further opportunities of benefits.

Associated with the righteousness, another Confucian ethics is faith or credit, which is seen as the foundation of a person: no standing, no credit. Confucianism believes credit is not only the premise of getting profit, but also principle of standing on one's own feet. Thus, faith or credit cannot be lost for contemporary profit; even contemporary profit can sacrifice to credit when necessary. This spirit of Confucian entrepreneurs not only establishes a good social image for the operators, but brings more business opportunities, and enables to keep their business evergreen. 


\section{Comparative Analyses of Chinese and Western "People-oriented" Management Philosophy}

\subsection{The Similarities between Chinese and Western People-oriented Management Philosophy}

There are a lot in common in Chinese people-oriented management tradition and western people-oriented management thought. First of all, they both attach great importance to individual status and value; and then, both are very concerned about people's needs and managing people by meeting their needs; Moreover, both stress the exemplary role of the manager, and so on.

\subsection{The Difference between Chinese and Western People-oriented Management Philosophy}

However, for the different cultural soils where people-oriented thinking was bred, and different historical trajectories, the gap between China and west is still large. The principal difference between them lies in cultural background. Ancient Chinese culture is an ethical culture, also duty-based, which emphasizes individual dedication and obligation to the group, and plays down the sense of individual rights; and also values individual belongingness to the group and realization of individual values in group. Generated in such cultural context, the humanism management thinking, inevitably, brings with a clear ethical color. In contrast, western culture is the rule of law and a right-based culture, which sees human as the center of the universe; and thus, human should pursue their own happiness, value, an independent personality and their own rights. On the basis of this management thinking, contract society takes shape, and then the legal society forms, and all these reflect in management philosophy is institutionalized and standardized management.

Second, difference exists in the management purposes. The starting point and destination of ancient Chinese humanism are beyond the individual. Guan Zhong's idea works on the stabilization of the state; Confucian benevolence and etiquette thoughts, Mencius' policy of benevolence claims, Xun Zi's benevolent government theory, mostly are also from the needs of government of ruling people, enriching the country and developing economy. Therefore, respecting, caring and loving people, are often means of bringing peace to country and maintaining social stability. However, in western management thought, human is the center of the universe, and all are ready for me: individual is the only purpose. Individuals realize their own values and happy life by working in specific organizations.

Third, difference lies in divergent status of people. Ancient Chinese "people-oriented" thought, focusing on people, can be considered as an instrument. Therefore, the person's status is often difficult to definitely establish, since it often has a great relationship with the ruling class's understanding of people's role, so there is a tight relationship between people's status and extent of rulers' concentration. In fact, ancient Chinese "people-oriented" idea is actually people-based thought, and subjects of the kingdom philosophy. Western "people-oriented" thinking pays too much attention to the individual values, and it tends to form individualism.

Fourth, difference exists in the management results. Ancient Chinese "people-oriented" management thinking has long been the strategy of sovereign to rule the country. It does play a role in stabilizing the country and reducing the burden on the people, but it will cause many negative effects because of its subjects of the kingdom culture. For example, people's lack of subjective personality, progressive sense, and lack of innovation, all those will slow the pace of social progress and development. Western thought lacks collective awareness and spirit, so it often results in a tendency to egoism.

\section{Going to Fusion from Collision of Eastern and Western People-oriented Management Philosophy}

To sum up, the foregoing analyses show, the management direction of eastern management thought, which focuses on culture and ethics' guidance, is different from that of western management thinking that emphasizes scientific management and efficiency. In other words, oriental management pursues harmony, while western pursues excellence. The pursuit of harmony and excellence are the primary and secondary differences, but there is no fundamental conflict. Under such circumstance of economic globalization and world integration, it is inevitable that harmony and excellence will go into unity gradually.

By other's faults, wise men correct their own. We have to admit, there has been certain gap between China and western countries now, and western cultures has constituted a powerful impact and pressure on Chinese culture. In this situation, Chinese people need to compare and contrast people-oriented management thoughts reflected in traditional Chinese culture and western cultures, in order to find out advantages and limitations of one's own. It attempts to learn the essence of western management culture under the premise of carrying forward traditional Chinese management culture, and find a suitable management ways for Chinese characteristics and cultural requirements to accelerate Chinese modernization process.

In short, in 21st century, with world economy gets more integrated and transnational business goes on expanding the scope of activities, joint venture is bound to develop rapidly, mutual benefit and win-win have 
become the cooperation basis of joint ventures between China and western countries. For the common interests, both sides should exploit advantages of each other, influence each other and make up their own limitations with the other's advantages. In operation philosophy, we should face up to the cultural differences and conflicts in Chinese and western joint venture, grasp the advantages and disadvantages, difference and similarity, to learn from each other and make up our own and create an integrated culture with their own characteristics in terms of operation organization, technique, production and management according to actual situations. It is foreseeable, scientific people-oriented management thinking is bound to concentrate on both the holistic and individual aspects in the future.

Therefore, the western management thought is about how to configurate ethical values and interpersonal relations during the management operations; in contrast, contemporary Chinese management philosophy is on how to establish operational behavior system based on the ethical values, how to understand the importance of operation norms. Therefore, both are highly complementary, and integration and mutual development is inevitable. In the 21st century, the world witnesses continuous economic development, increasingly regional cooperation, in-depth impact of economic globalization, the collision of civilizations, exchanges and cooperation have become the main topics and the eternal melody of the globalization process. Nowadays, communication between different cultures and values and harmonious development become inevitable trends. In conclusion, the main orientation of future management development should be eastern management culture as its core, and absorb scientific achievements from western management culture, to enrich the treasure trove of management philosophy so as to promote the great fusion of eastern and western management cultures.

\section{References}

Cai, Houqing. (2000). Similarity and Difference between Confucian Management Thought and Contemporary Western Management Thoughts. China Economist, 12, 22-23.

Cai, Xiqin. (2006). The Confucius Says. Beijing: Sinolingua Press.

Chen, Shigao. (2006). Cultural Difference Analyses of Chinese and Western Management Thoughts. Gansu Agriculture, 9, 142-143.

Horn, A. Daniel. (2000). The Evolution of Management Thought. Beijing: China Social Sciences Press.

Huang, Yuxiang. (2000). An Introduction to Enterprise Management. Beijing: Higher Education Press.

Maslow A. H. (1943). A Theory of Human Motivation. Psychological Review, 50, 370-396. http://dx.doi.org/10.1037/h0054346

Philosophy Department of Beijing University. (1982). Ancient Greek-Rome Philosophy. Beijing: The Commercial Press.

Xu, Qingrui. (2000). Management. Beijing: Higher Education Press.

Yan, Shifu. (1999). Oriental Management. Beijing: China Broadcasting and Television Press.

Yang, Hongjuan. (2000). A Comparative Study of the Chinese and Western Management Thoughts. Journal of Kunming University of Science and Technology, 2, 26-30.

Zhong, Mang. (2007). The Analects. Beijing: China Children Press. 